Agnieszka K. Choinska, Andrzej Szpak

(Uniwersytet Medyczny w Białymstoku)

\title{
Udział w decyzji o leczeniu a interakcje społeczne pacjentów onkologicznych
}

\section{Wstęp}

Interakcje zachodzące między pacjentem a personelem medycznym są przykładami interakcji zogniskowanych, które charakteryzują się orientacją na przedmiot - problem, chorobę nowotworowa pacjenta. Pacjent, wchodzac $\mathrm{w}$ rolę chorego i przyjmując wszystkie związane $\mathrm{z}$ nia obowiązki i przywileje, decyduje się na zalecona przez lekarza terapie medyczna. Środki farmakologiczne, które przyjmuje, zabiegi medyczne, jakim się poddaje, wpływają na jego zachowanie, często zmieniając nastrój i samopoczucie, a nawet wygląd osoby. W tym okresie terapii, nowego znaczenia nabieraja interakcje pacjenta $\mathrm{z}$ otoczeniem społecznym (Goffman 2005:32-76). Wyrażają się one w zmianie percepcji otoczenia społecznego, akceptujaccym bądź negujaccym stosunkiem do świata, depresją, niechęcią do nawiązywania, bądź w postawie wycofania ze względu na poczucie niższej wartości spowodowanej doświadczeniem choroby. Pacjent nie pozostaje jednak osoba wyłączona ze społecznych kontaktów, wręcz przeciwnie, otrzymuje nowe „impulsy”, które motywuja go do określonych działań i decyzji o charakterze społecznym. Pojawiają się pytania: Jak pacjenci oceniaja swoje zaangażowanie w decyzję o leczeniu?; Czy zauważają oni zmiany w kontaktach społecznych w okresie choroby i leczenia?; W jaki sposób udział w terapii wpływa na ocenę interakcji społecznych pacjentów?

Odpowiedzi na wyżej postawione pytania dostarczyły badania socjologiczne przeprowadzone od lipca do listopada 2011 r. oraz od października do grudnia 2012 r. wśród pacjentów hospitalizowanych w Białostockim Centrum Onkologii. Chociaż zebrano obszerny materiał badawczy, w niniejszym opracowaniu zostaną zaprezentowane i omówione tylko wybrane zagadnienia. 


\section{Charakterystyka badanej populacji}

Badaniem zostali objęci pacjenci BCO zarówno kobiety, jak i mężczyźni w wieku aktywności zawodowej 20-60 lat, poddani terapii w Klinice Onkologii (26,7\% badanych) i na następujących oddziałach: Onkologii Ginekologicznej (22\%), Radioterapii $(20,3 \%)$ oraz Chemii Dziennej (31\%). Ogółem zbadano 187 pacjentów: 117-kobiet i 70-mężczyzn.

Największy odsetek $(42,7 \%)$ wśród respondentów stanowiły kobiety z nowotworami piersi, jajników i szyjki macicy. Zebrane dane potwierdzają wysoki stopień zachorowalności kobiet, co stwierdzono w innych, wcześniejszych opracowaniach (Krzyżak i in. 2008:110-119, Zatoński i in. 2009:13, 25, 53; Zatoński 2010:17-18, 21-22). Ponadto, kobiety stanowią wyższy niż mężczyźni odsetek pacjentów korzystających z terapii medycznej, a w konsekwencji ich reprezentacja $\mathrm{w}$ badaniach jest znacząco wyższa.

Wśród mężczyzn przyczyny zachorowalności były bardziej rozproszone statystycznie. Największy odsetek, 19,8\% z liczby respondentów, to pacjenci cierpiacy na nowotwory przewodu pokarmowego, w tym wątroby. Na uwage zasługuje fakt, iż w czasie wywiadu $12,3 \%$ pacjentów unikało pełnej artykulacji choroby (np. nie określało rodzaju nowotworu i nie lokalizowało go $\mathrm{w}$ przestrzeni ciała), a 2,6\% nie miało świadomości choroby (osoby te odwoływały się do wiedzy lekarzy bądź członków rodziny), pomimo uczestnictwa w terapii medycznej. Dane te pochodza z osobistych deklaracji i wiedzy pacjentów na temat choroby.

Ważnym elementem charakterystyki badanej grupy jest bliskość, bądź oddalenie respondentów w codziennych interakcjach z podmiotami społecznymi. Ważne jest więc czy pacjent mieszka sam, czy prowadzi gospodarstwo domowe wspólnie z inną osobą bądź osobami. Większość badanych mieszkała z rodzina $(71,7 \%)$, niektórzy z osobą najbliższą $(17,1 \%)$ (jednym $\mathrm{z}$ członków rodziny lub partnerem etc.), najmniej było osób samotnych $(11,2 \%)$.

Podstawowe pytanie badawcze postawione w tej pracy brzmi: Czy stopień $\mathrm{w}$ jakim pacjent uczestniczy $\mathrm{w}$ decyzji o leczeniu jest związany $\mathrm{z}$ percepcja zmian w interakcjach społecznych? Analizowane będa dwa obszary interakcji: terapeutyczna i społeczna. W tym celu posłużono się w badaniu metodą ilościowa (ankieta) i jakościową (wywiad z pytaniami otwartymi). Ankieta zawierała, między innymi, pytania dotyczace uczestnictwa pacjentów w podejmowaniu decyzji o leczeniu oraz wpływu choroby i leczenia na kontakty społeczne i zawodowe. Wybrano cztery liniowe, analogowe skale samooceny interakcji społecznych pacjenta, które dotyczyły następujących zagadnień: zdolności do wykonywania czynności codziennych, podejścia do pracy i obowiązków z nią związanych, 
kontaktów ze znaczącym innym oraz ocenę wpływu zmian w/na ciele, spowodowanych choroba i leczeniem, na interakcje w środowisku społecznym. Pogłębiony wywiad był uzupełnieniem ankiety na wyżej wymienione tematy. Pytania otwarte pozwoliły respondentom na szczegółowe wyrażenie swoich poglądów i odczuć. Wywiad i ankieta, przeprowadzone łacznie z tym samym respondentem, trwały średnio około 25 minut.

\section{Udział pacjenta w decyzji o leczeniu}

W badaniu uwzględnionych zostało pięć możliwości (skala Likerta) uczestnictwa pacjenta $\mathrm{w}$ decyzjach dotyczących terapii:

a) pacjent dominujacy - samodzielnie podejmujacy decyzję o terapii,

b) pacjent dominujaco-refleksyjny, który sam podejmuje decyzje o terapii, ale uwzględnienia opinię lekarzy specjalistów,

c) pacjent wspótpracujacy, otwarty i wchodzacy w dialog ze swoim lekarzem i wspólnie z nim decydujacy o terapii,

d) pacjent podporzadkowany-refleksyjny, uwzględniający przede wszystkim decyzje lekarskie, ale również domagający się uznania własnej opinii w sprawie terapii,

e) pacjent podporzadkowany, całkowicie zależny od decyzji lekarza, nie zgłaszajacy własnych uwag $\mathrm{w}$ sprawie leczenia (Arora $\mathrm{i}$ in. 2000:335-341, Degner i in. 1997:29-30, Davison i in. 2004:48-50, Stacey i in. 2008:295-300, Sutherland i in. 1989:261, Strull i in. 1984:2992).

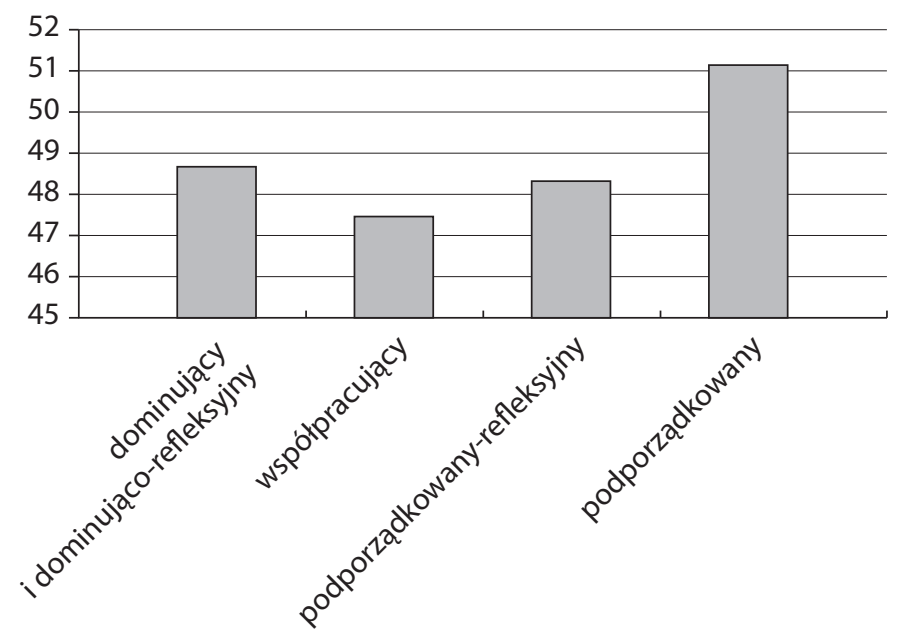

Wykres 1. Udział w decyzji o leczeniu a wiek badanych

Źródło: opracowanie własne 
Przed rozpoczęciem analizy danych, w celu uzyskania odpowiedniej liczebności respondentów w poszczególnych grupach, połączono pacjentów dominujących - a $(\mathrm{N}=3)$ i dominująco refleksyjni - b $(\mathrm{N}=27)$ w jedną kategorię statystyczną. Otrzymano liczebność 30 pacjentów $(\mathrm{a}+\mathrm{b})$ spełniająca wymogi statystyczne dla porównań między grupami.

Analiza testem Kruskala-Wallisa wykazała, że wiek badanych respondentów nie różnicuje porównywanych grup. Jej wynik jest nieistotny statystycznie, co oznacza, że porównywane grupy nie różnią się pod względem średniego wieku $\left(\mathrm{Chi}^{2}(3)=4,33 ; \mathrm{p}=0,28\right)$. Można jednakże podkreślić, że średnie wieku w kategoriach uczestnictwa w decyzji o leczeniu są wyższe wśród pacjentów podporządkowanych. Najmłodszym wiekiem charakteryzuja się pacjenci współpracujacy, a pacjenci dwóch pozostałych kategorii, dominujaccych i dominujaco-refleksyjnych oraz podporządkowanych refleksyjnych, reprezentuja ten sam poziom wiekowy.

Tabela 1. Średni procentowy udział kobiet i mężczyzn w decyzji o leczeniu

\begin{tabular}{|c|c|c|c|c|}
\hline \multirow{2}{*}{\multicolumn{2}{|c|}{ Udział w decyzji: }} & \multicolumn{2}{|c|}{ Pleć } & \multirow{3}{*}{$\begin{array}{c}\text { Ogółem } \\
30\end{array}$} \\
\hline & & \multirow{2}{*}{$\frac{\text { mężczyźni }}{18}$} & \multirow{2}{*}{$\begin{array}{c}\text { kobiety } \\
12\end{array}$} & \\
\hline a, b) dominujacy & liczebność & & & \\
\hline i dominująco- & $\%$ z udział w decyzji & 60,0 & 40,0 & 100,0 \\
\hline refleksyjny & $\%$ z płeć & 25,7 & 10,3 & 16,0 \\
\hline \multirow{3}{*}{ c) współpracujący } & liczebność & 18 & 30 & 48 \\
\hline & $\%$ z udział w decyzji & 37,5 & 62,5 & 100,0 \\
\hline & $\%$ z płeć & 25,7 & 25,6 & 25,7 \\
\hline \multirow{3}{*}{$\begin{array}{l}\text { d) podporzadkowany- } \\
\text { refleksyjny }\end{array}$} & liczebność & 18 & 35 & 53 \\
\hline & $\%$ z udział w decyzji & 34,0 & 66,0 & 100,0 \\
\hline & \% z płeć & 25,7 & 29,9 & 28,3 \\
\hline \multirow{3}{*}{ e) podporządkowany } & liczebność & 16 & 40 & 56 \\
\hline & $\%$ z udział w decyzji & 28,6 & 71,4 & 100,0 \\
\hline & \% z płeć & 22,9 & 34,2 & 29,9 \\
\hline \multirow{3}{*}{ ogółem } & liczebność & 70 & 117 & 187 \\
\hline & $\%$ z udział w decyzji & 37,4 & 62,6 & 100,0 \\
\hline & $\%$ z płeć & 100,0 & 100,0 & 100,0 \\
\hline
\end{tabular}

Źródło: opracowanie własne.

W celu zbadania związku między częstotliwością występowania kobiet i mężczyzn w każdej z czterech badanych grup $(a+b, c, d, e)$ przeprowadzono analizę testem $\mathrm{Chi}^{2}$. Wyniki pokazuja, że związek między dwiema analizowanymi zmiennymi jest istotny statystycznie $\left(\mathrm{Chi}^{2}(3)=8,67 ; \mathrm{p}<0,01\right)$. Współczynnik V Cramera równy 0,215 wskazuje 
jednak, że jest to relacja o stosunkowo niewielkiej sile. Mężczyźni wyprzedzaja kobiety w prezentowaniu dominującego i dominujaco-refleksyjnego podejścia do leczenia (60\% vs 40\%). Kobiety z kolei częściej niż mężczyźni przejawiaja styl współpracujacy, podporządkowany - refleksyjny oraz podporzadkowany. Ten ostatni styl jest w grupie kobiet najbardziej popularny. Tabela 1 przedstawia szczegółowo procentowy udział pacjentów w podejmowaniu decyzji o leczeniu.

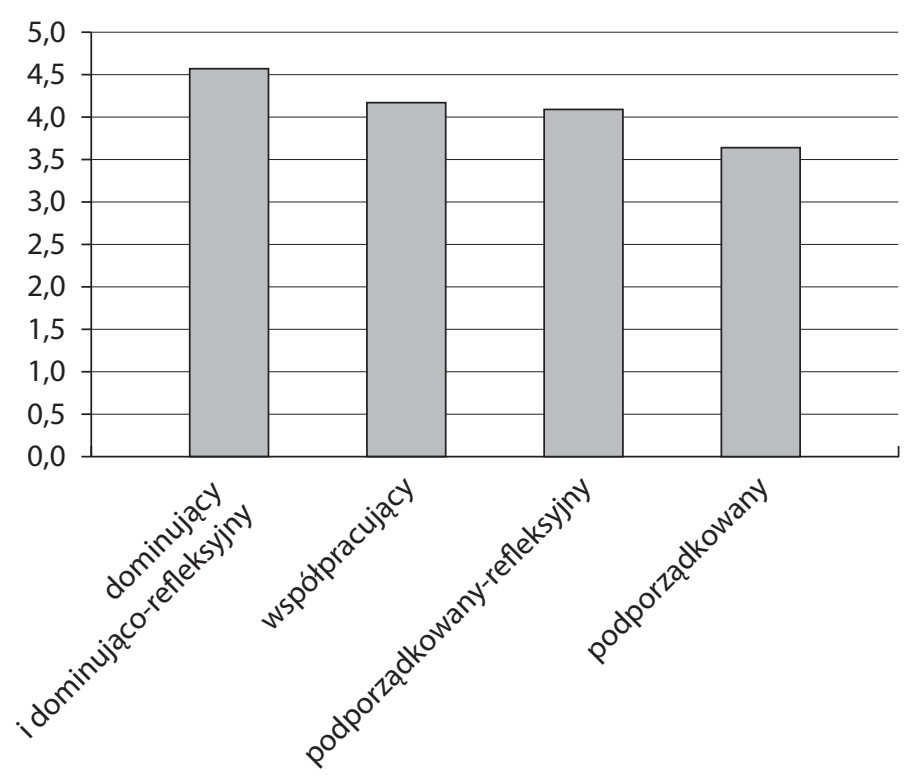

Wykres 2. Udział w decyzji o leczeniu a wykształcenie respondentów Źródło: opracowanie własne

Badano także, czy wykształcenie, które zazwyczaj różnicuje podmioty społeczne w wyborze upodobania i stylu bycia, wpływa na przynależność do odpowiedniej kategorii udziału w decyzji o leczeniu w sposób istotny statystycznie? Analiza testem Kruskala-Wallisa pokazuje, że różnica zaznacza się jedynie na poziomie tendencji statystycznej $\left(\mathrm{Chi}^{2}(3)=7,11 ; \mathrm{p}=0,068\right)$. Porównania parami wykazuja statystycznie na poziomie $\mathrm{p}<0,05$, pod względem wykształcenia, różni sie jedynie grupa $a+b$ z grupa e. Średnie arytmetyczne zilustrowane na poniższym wykresie pokazuja, że osoby z grupy dominującej i dominująco-refleksyjnej charakteryzuja się istotnie wyższym poziomem wykształcenia od osób z grupy podporządkowanej. Między pozostałymi grupami brak jest znaczących różnic. 


\section{Percepcja zmian w interakcjach społecznych}

W okresie choroby zmienia się percepcja środowiska społecznego i zachowanie pacjenta. Otoczenie społeczne również reaguje na nową sytuacje poprzez odpowiednie decyzje, które dokonuja się w grupach przynależności społecznej, takich jak: rodzina, środowisko pracy, grupy przyjacielskie i sassiedzkie. Pacjenci nie zawsze sa świadomi zachodzacych przeobrażeń. Wielu z nich nie wie, jak odpowiadać na nieoczekiwane reakcje otoczenia, które wyrażają się nagłym zainteresowaniem, chęcia pomocy choremu, ale również odrzuceniem, brakiem współpracy czy niezrozumieniem i izolacja. Pacjenci często stoja przed problemem reorganizacji życia społecznego w aspekcie osobistym i zawodowym. Podejmuja trudne decyzje, otrzymuja nowe obowiązki, wchodza w nowe kontakty społeczne. Zastanawiają się, jak pogodzić dotychczasowe życie „człowieka zdrowego”, z tym nowym - „człowieka z nowotworem”. Chorzy zauważaja konieczność odpowiedniego działania i aktywnego tworzenia zróżnicowanych interakcji. Podstawa do opracowania tych społecznych strategii jest właściwa ocena zmian w interakcjach społecznych, która powinna być dokonana przez pacjenta. Wysoka aktywność $\mathrm{w}$ tworzeniu interakcji zależy bowiem od stopnia w jakim pacjent potrafi ocenić zmiany w kontaktach z podmiotami społecznymi (grupowymi i jednostkowymi). Pacjent obserwuje otoczenie, zauważa odmienności bądź je ignoruje, ocenia skale tych zmian począwszy od interakcji ze znaczącym innym (ZI - osoba bliska, związana emocjonalnie z pacjentem, z którą miał on kontakt przynajmniej raz w tygodniu), poprzez interakcje rodzinne i przyjacielskie oraz relacje w środowisku pracy. Istotna jest także ocena codziennej życiowej aktywności (wykonywanie zwykłych domowych prac i obowiązków), na która składa się również doświadczenie chorego ciała (zmian w/na ciele) i jego wpływ (mniej/bardziej znaczacy) na interakcje (Goffman 2005:35-37, Weiss, Lonnquist 2006:58-60, 126-130).

Zmiany deklarowane przez respondentów związane sa przede wszystkim z czynnościami dnia codziennego i dokonały się one w stopniu określonym na poziomie $78.29 \%$ dla całej populacji badanych pacjentów. Interakcje w środowisku pracy i podejście do obowiązków zawodowych zmieniły się w ocenie respondentów o 52,66\%. Zmiany $\mathrm{w}$ kontaktach ze znaczacym innym dokonały się w 30,14\%. Natomiast, wygląd zewnętrzny, spowodowany chorobą wpływa - według pacjentów - w $22,68 \%$ na interakcje w środowisku społecznym.

Test t Studenta dla prób niezależnych umożliwił szczegółowe porównanie percepcji zmian w interakcjach społecznych w grupie kobiet 
i mężczyzn. Wykonano serię czterech testów z uwzględnieniem przyjętej skali samooceny interakcji w wymienionych obszarach. Wyniki świadczą o zupełnym braku istotności statystycznej między kobietami a mężczyznami w zakresie analizowanych zagadnień. Średnie kobiet i mężczyzn prezentuje poniższa tabela 2 .

Tabela 2. Stopień deklarowanych zmian w interakcjach społecznych ze względu na płeć

\begin{tabular}{|l|l|r|c|c|}
\hline \multicolumn{1}{|c|}{ Zmiana } & \multicolumn{1}{|c|}{ Płeć } & N & Średnia & $\begin{array}{c}\text { Odchylenie } \\
\text { standardowe }\end{array}$ \\
\hline \multirow{2}{*}{$\begin{array}{l}\text { w czynnościach dnia } \\
\text { codziennego }\end{array}$} & mężczyźni & 70 & 79,1571 & 27,42930 \\
\cline { 2 - 5 } & kobiety & 117 & 77,4278 & 32,24482 \\
\hline \multirow{2}{*}{ w podejściu do pracy } & mężczyźni & 70 & 50,9450 & 37,18832 \\
\cline { 2 - 5 } & kobiety & 117 & 54,3650 & 36,74740 \\
\hline \multirow{2}{*}{$\begin{array}{l}\text { w kontaktach } \\
\text { z najbliższa osoba }\end{array}$} & mężczyźni & 70 & 29,3029 & 33,60704 \\
\cline { 2 - 5 } \multirow{2}{*}{$\begin{array}{l}\text { wobiety } \\
\text { zewngętązie }\end{array}$} & 117 & 30,9718 & 35,83527 \\
\cline { 2 - 5 } & mężczyźni & 70 & 22,9743 & 28,20082 \\
\hline
\end{tabular}

Źródło: opracowanie własne.

W celu sprawdzenia, czy istnieje związek między wiekiem badanych osób a ich odpowiedziami na pytania dotyczace zmian w interakcjach społecznych, przeprowadzono analizę korelacji ze współczynnikiem $r$ Pearsona. Wyniki pokazuja, że wiek jest związany z dwiema odpowiedziami na pytania: kontakty ze znaczacym innym oraz wpływ zmian fizycznych na interakcje w środowisku społecznym. Związki sa jednak istotne jedynie na poziomie tendencji statystycznej i o bardzo niewielkiej sile (mniejsze niż $\mathrm{r}=0,15$ ). Ponadto mają charakter ujemny, co oznacza, że wraz ze wzrostem wieku maleja wyniki w zakresie percepcji zmian w kontaktach $\mathrm{z}$ najbliższymi oraz zmian w wyglądzie zewnętrznym. Takie zmiany nie są zauważane, przestaja mieć znaczenie bądź nie zachodzą.

Podobnie jak w powyższym punkcie, także w przypadku wykształcenia, wykonano analize korelacji lecz tym razem ze współczynnikiem rho Spearmana. Efekty tej analizy wskazuja na istotny statystycznie związek na poziomie $\mathrm{p}<0,05$ między wykształceniem a wynikami na skali kontaktów z najbliższymi oraz na skali oceny wyglądu zewnętrznego. Korelacje są również raczej słabe, ale tym razem o znaku dodatnim co oznacza, że im wyższe jest wykształcenie badanych, tym większe są wyniki na dwóch wyżej wymienionych skalach. Pacjenci z wyższym wykształceniem dostrzegają więcej zmian. 
Zaprezentowane powyżej wyniki badań znajduja swoją kontynuacje $\mathrm{w}$ analizie danych jakościowych. Respondenci, w wywiadach bezpośrednich, zwrócili uwage na dokonujące się szczególne zmiany w czynnościach dnia codziennego oraz podejściu do pracy. Zmiany te przez mężczyzn i kobiety postrzegane są w takim samym stopniu i na ogół sa związane z ograniczeniem bądź reorganizacją codziennej aktywności pacjenta. Stają się więc przyczyną poszukiwania kontaktu i pomocy w wykonywaniu prac i obowiązków przypisanych osobie. Aktywność codzienna i podejście do obowiązków zawodowych są również najbardziej podstawowymi i czułym wskaźnikami ich funkcjonalności społecznej, a więc normalności i zdrowia: „Pomagam rodzinie, chociaż nie moge już pracować, tak jak dawniej”, „Jeżdżę na rowerze w wolnym czasie, co sprawia mi wielka radość”, „Jestem w telefonicznym kontakcie z moimi współpracownikami i przełożonym. Wiem, na bieżąco, co się dzieje w moim miejscu pracy”, „Organizuję moja prace w domu” etc.

Pacjenci poddaja środowisko życia i kontakty społeczne natychmiastowej ewaluacji, przypisując zmianom $\mathrm{w}$ interakcjach następujące cechy:

- dodatnie (pozytywne), do których należy zainteresowanie ze strony otoczenia osoba chora oraz jej potrzebami i problemami, ale pod warunkiem, że zainteresowanie nie przejawia się nadopiekuńczością: np. „Nie chcę, by się nade mną litowano”, „Nie lubię przesady”, „Nie chcę mówić ciagle o tym samym” etc.;

- ujemne (negatywne), to zerwanie kontaktów z osobą chora i traktowanie przedmiotowe: np. „Po miesiacu, od momentu kiedy dowiedziano się o mojej chorobie, zostałem zwolniony z pracy", „Dopiero teraz wiem, kto jest moim przyjacielem”, „Mąż dał mi odczuć, że jestem bez wartości i znaczenia. Myślę, że w tej postawie wyraziła się jego bezradność wobec choroby. Nie tylko my powinniśmy rozmawiać z psychologami, ale przede wszystkim nasze rodziny";

- niezmienność w interakcjach (wartościowana pozytywnie) - jest synonimem ciagłości zdrowotnej, daje pacjentom poczucie bezpieczeństwa w poruszaniu się w sieci kontaktów społecznych: np. „nic się nie zmieniło, wszystko przebiega normalnie”, ,jest tak, jak dawniej'. Pacjenci, nawet z głęboka świadomościa choroby, staraja się utrzymać status quo, posuwając się czasami do pozorowania niezmienności w interakcjach w różnych kontekstach społecznych: „Codziennie, wcześnie rano wkładam peruke, aby dzieci (małe) nie widziały, że nie mam włosów”, „Koleżanki w pracy pytaja, czy ostatnio byłam u fryzjera, gdyż tak ładnie wyglądam. Nie mówiłam, że jestem chora”, „Nie rozmawiam z żoną i dziećmi o chorobie, 
to takie smutne". Cechą charakterystyczna takich działań pacjentów jest często pozorowana funkcjonalność: np. „Nie mówię, że znowu mam nawrót choroby, gdyż obawiam się reakcji rodziny i konsekwencji w miejscu pracy. W szpitalu bywam na badaniach kontrolnych, a nie na chemii". Pacjenci chca mieć poczucie, że panują nad sytuacja, „zarządzają" doświadczeniem choroby. Oni decyduja, kto i o czym ma wiedzieć, w konsekwencji traca właściwa perspektywę swego realnego funkcjonowania i relacji społecznych. Zapominaja o tym, że w chorobie i leczeniu wraz z nimi zmienia się odniesienie do środowiska społecznego nawet wówczas, gdy to środowisko nie wie nic na temat stanu ich zdrowia.

Ponadto, badani nieustannie oceniają swój zewnętrzny wygląd i mają świadomość, że jest on również poddawany społecznej interpretacji. Ciało, nawet chore, w swoim zewnętrznym wyrazie posiada niewatpliwe znaczenie komunikacyjne i wpływa na nowy kształt interakcji (Goffman 2005:33). Na uwage zasługuje fakt, że mężczyźni i kobiety w takim samym stopniu dostrzegaja społeczne skutki zmian (tabela 2), które dokonały się w/na ciele (jako efekt choroby i leczenia). Kobietom trudniej przyznać się do tych widocznych zależności, gdyż doświadczenie społeczne jest bardziej bolesne. Należy dodać, że w wymiarze osobistym i rodzinnym, kobiety mocniej przeżywają każda niekorzystna odmienność estetyczną oraz jej społeczne konsekwencje: np. „Nie chce, aby koledzy mojego syna mówili, że ma chora matkę i źle go traktowali. Nie chce, żeby odczuwał wstyd. Dlatego dbam o siebie”.

\section{Zależności między obszarami interakcji w okresie choroby i leczenia}

Zebrany materiał badawczy pozwala na zbadanie zależności, jakie istnieją między uczestnictwem w podejmowaniu decyzji o leczeniu a deklarowanymi zmianami w interakcjach społecznych. Podobnie, jak w powyższych punktach, wykonano test Kruskala-Wallisa, który wykazał, że żaden z czterech współczynników nie jest istotny statystycznie. Wyniki są nieistotne co najmniej na poziomie $p>0,14$. Oznacza to, że bez względu na rodzaj decyzji o leczeniu, badani uzyskuja podobne wyniki w zakresie oceny czynności dnia codziennego, obowiązków zawodowych, kontaktów z najbliższymi oraz w ocenie wpływu zmian cielesnych na kontakty społeczne.

Porównując średnie (wykres 3) w poszczególnych kategoriach udziału w decyzji o leczeniu możemy powiedzieć, że zmiany w czynnościach 
dnia codziennego sa najbardziej dostrzegane we wszystkich porównywanych grupach, ale najwyższy wskaźnik osiaga kategoria pacjentów współpracujących - c. W pozostałych kategoriach różnice sa znikome. Średnie percepcji zmian podejścia do pracy i związanych z nią obowiązków rosną wraz z podporządkowaniem pacjenta decyzjom o leczeniu i najcześsiej dostrzegaja je pacjenci grupy E. Dane jakościowe potwierdzaja że, przyczyna tego zjawiska jest złożona i nie należy jej utożsamiać jedynie z pogarszajacym lub polepszającym się stanem zdrowia pacjenta. Trzeba również zwrócić uwagę na to, że pacjenci podporządkowani to wielokrotnie osoby zbliżajace się do wieku emerytalnego, a ich stan zdrowia nie motywuje do większej aktywności w podejmowaniu obowiązków zawodowych, a także środowisko pracy, w zaistniałej sytuacji choroby, nie stawia przed nimi wielkich wymagań.

$\square$ w podejściu do pracy

w kontaktach z osobą najbliższą $\square$ w czynnościach dnia codziennego

$\square$ w wyglądzie zewnętrznym

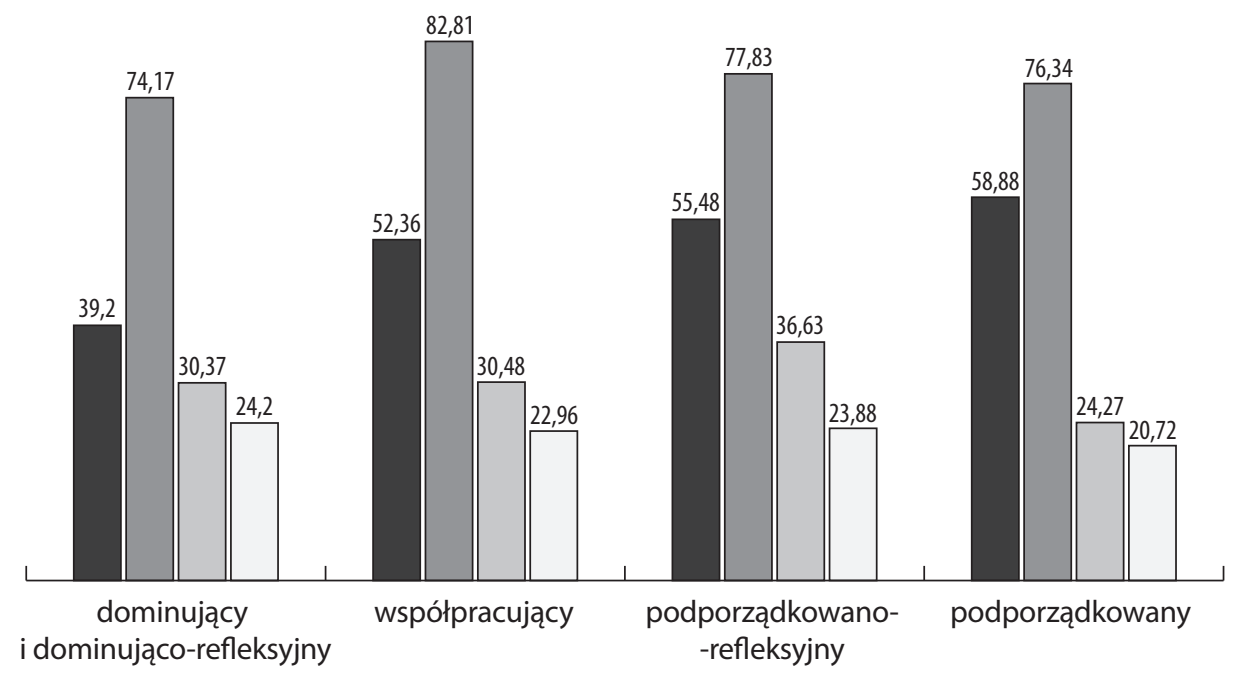

Wykres 3. Udział w decyzji o przebiegu terapii a stopień deklarowanych zmian w wybranych przez pacjenta interakcjach społecznych (średnia)

Źródło: opracowanie własne

Jeśli chodzi o kontakty ze znaczącym innym (osoba najbliższa), to średnie statystyczne, wykazuja zrównoważony i niewysoki poziom percepcji zmian w poszczególnych kategoriach udziału pacjenta w decyzji o leczeniu. Najmniej zmian, bo tylko $24,27 \%$, zauważaja pacjenci podporządkowani (w pozostałych grupach ten wskaźnik jest trochę wyższy). Dlaczego pacjenci podporządkowani deklaruja najniższą ocenę 
zmian w kontaktach ze znaczacym innym? Aby odpowiedzieć na to pytanie należy odwołać się znowu do danych jakościowych. W okresie choroby i leczenia pacjenci podporządkowani (bardziej niż inne kategorie respondentów) licza na środowisko rodzinne i przyjacielskie. Z takich właśnie środowisk wywodzą się znaczacy inni - osoby będące wsparciem, okazujące wysoki stopień życzliwości i intensywnego zainteresowania oraz kontaktów z chorym. Pacjent, poddając się relacjom z nimi, ma poczucie zaangażowania w ciagłość wydarzeń życiowych, których nie przerwała choroba, ograniczenia $\mathrm{z}$ nia związane i nowe obowiązki.

Percepcja zmian w wyglądzie zewnętrznym utrzymuje się na najniższym poziomie procentowym w czterech kategoriach pacjentów. Pacjenci wszystkich grup udziału w decyzji o leczeniu nisko oceniaja wymiar społecznego oddziaływania chorego ciała. Samo pojawienie się choroby nie było motywacją do spostrzeżeń i ocen w tej kwestii, dopiero poważne zmiany w wyglądzie, spowodowane inwazyjna terapią medyczna, przyczyniały się do śmiałych ocen dotyczacych reakcji środowiskowych i odczucia własnego chorego ciała. Symbolika stawała się nie do zniesienia - niepodobieństwo, nierozpoznawalność sąsiedzka, lokalna i w miejscu pracy, wstyd, opóźnienie w wykonywaniu społecznych zadań - zaburzały nie tylko dotychczasowe interakcje na wszystkich poziomach, ale niszczyły poczucie tożsamości społecznej.

\section{Podsumowanie}

1. Pacjenci dominujacy i dominujacco refleksyjni oraz współpracujacy to kategorie najmłodsze pod względem wieku, a jednocześnie wykazujące się wyższym wykształceniem w porównaniu z kategoriami pacjentów podporządkowanych. Można więc mówić o pewnej międzypokoleniowej zmianie stylu zaangażowania pacjenta w decyzję o leczeniu, gdyż młodsze pokolenia wykazuja się zwiększona gotowością do współpracy oraz przejęcia odpowiedzialności za decyzje o terapii medycznej.

2. Tendencje statystyczna potwierdzaja dane jakościowe. Świadomość zdrowotna -wiedza na temat choroby, otwartość w rozmowie o chorobie jest wyższa w grupach pacjentów dominujacych i współpracujących, czyli młodszych i bardziej wykształconych. Ta tendencja demograficzna utrzymuje się nawet wtedy, gdy pacjent zalicza się do kategorii podporządkowanych refleksyjnych.

3. Pozorowana niezmienność i funkcjonalność w interakcjach społecznych dotyczą pacjentów z kategorii współpracujących oraz podporządkowanych refleksyjnych. Taki wniosek możemy wysnuć 
na podstawie danych jakościowych. Cechy demograficzne (młody wiek i wyższe wykształcenie) pełnią tu znowu funkcję determinująca pacjentów w sposobie postrzegania oraz reagowania na zmiany w kontaktach społecznych.

4. Pozorowanie niezmienności i funkcjonalności najczęściej podejmowane jest $\mathrm{w}$ interakcjach ze znaczacym innym oraz $\mathrm{w}$ miejscu pracy, szczególnie w przypadku zmiany zatrudnienia lub ograniczenia odpowiedzialności zawodowej.

5. Pacjenci podporządkowani, chociaż stanowią grupe najstarsza wiekiem, to wykazuja się wysoką ocena zmian w podejściu do obowiązków zawodowych. Nie są to jednak osoby wyizolowane społecznie lecz takie, które porządkują swoje dotychczasowe doświadczenie interakcyjne poprzez budowanie wyselekcjonowanej sieci interakcji społecznych, opartej głównie o środowisko osób najbliższych z uwzględnieniem najbardziej koniecznych aktywności społeczno-profesjonalnych.

\section{Bibliografia}

Arora N. K., McHorney C.A. (2000), Patient Preferences for Medical Decision Making. Who Really Wants to Participate?, „Medical Care”, 38, s. 335-341.

Goffman E. (2005), Piętno. Rozważania o zranionej tożsamości, Gdańskie Wydawnictwo Psychologiczne, Sopot.

Davison B.J., Parker P.A., Goldenberg S.L. (2004), Patients' preferences for communicating a prostate cancer diagnosis and participating in medical decision-making, „B. J. U. International”, 93, s. 47-51.

Degner L.F, Sloan J.A, Venkatesh P. (1997), The Control Preferences Scale, „Can. J. Nurs Res.", 29, s. 21-43.

Krzyżak M., Maślach D., Juczewska M., Maksimowicz K., Lasota W., Szpak A. (2008), Stopień zaawansowania raka piersi wśród kobiet $w$ województwie podlaskim $w$ latach 2001-2002 - badania populacyjne, „Problemy Higieny i Epidemiologii”, 89(11), s. $110-119$.

Stacey D., Samant R., Bennett C. (2008), Decision making in oncology: A review of patient decision aids to support patient participation, „C. A. Cancer J. Clin.”, 58, s. 293-304.

Strull W. M., Lo B., Charles G. (1985), Do Patients Want to Participate in Medical Decision Making?, „JAMA”, 252, s. 2990-2994.

Sutherland H. J., Llewellyn-Thomas H. A., Lockwood G.A., Tritchler D. L., (1989), Cancer patient: their desire for information and participation in treatment decision, „Journal of the Royal Society of Medicine”, 82, s. 260-263.

Weiss G.L., Lonnquist L.E. (2006), Sociology of Health, healing and illness, Prentice Hall, New Jersey.

Zatoński W., Didkowska J., Wojciechowska U. (2009), Nowotwory złośliwe w Polsce, Centrum Onkologii - Instytut im. Marii Skłodowskiej-Curie, Warszawa.

Zatoński W. (red.) (2010), Europejski kodeks walki z rakiem, Centrum Onkologii - Instytut im. Marii Curie-Skłodowskiej, Warszawa. 


\section{Participation in the medical decision making and social interactions of oncologic patients}

The article presents chosen aspects of the research conducted in the Białystok Oncology Centre (BOC) over the years $2011-2012$. The aim of the study was to obtain data concerning the patient's participation in the medical decision making and impact of the disease and medical therapy on social interactions. The study group consisted of patients hospitalised in medical departments of the Białystok Oncology Centre. The choice of respondents was made according the following criteria: patients with a malignant neoplasm (both male and female), patients currently undergoing a varied medical therapy at the BOC, and patients at a professionally active age. Different categories of the patient's participation in the medical decision making are specified and analysed in the paper. The article also presents the results of the patients' self-assessment of their capabilities to cope with everyday routine activities, attitude to professional duties attributed to them and contacts with the closest person - significant other, as well as evaluation of the effect of external changes caused by the disease and its treatment on social interactions. The following demographic factors have been taken into consideration in the analysis of the results and their interpretation: age, sex and education.

Key words: oncologic patients, participation in the therapy, social interaction.

\section{Podziękowania}

Moje podziękowania chciałabym skierować do pani dyrektor Białostockiego Centrum Onkologii dr Marzeny Juczewskiej oraz pana prof. dr. hab. Marka Wojtukiewicza, pani dr Beaty Maćkowiak-Matejczyk, pana dr. Tomasza Maksimowicza oraz pani dr Bogumiły Czartoryskiej-Arłukowicz za wyrażenie zgody na przeprowadzenie badań w kierowanych przez nich oddziałach BCO. Dziękuję również wszystkim pozostałym pracownikom i pacjentom za okazaną życzliwość i zainteresowanie problematyką badawczą. 